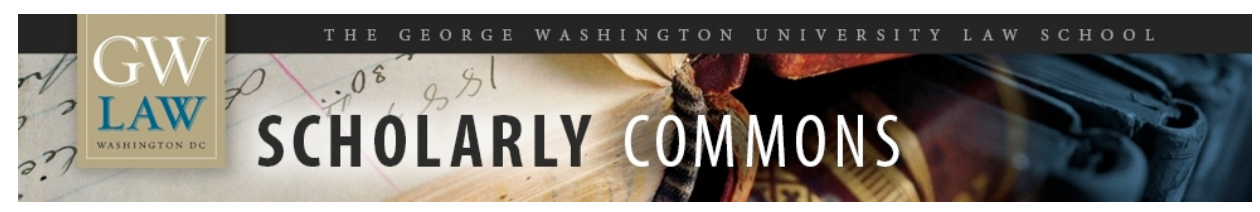

\title{
Proper and Improper Use of Other Act Evidence
}

Stephen A. Saltzburg

George Washington University Law School, ssaltz@law.gwu.edu

Follow this and additional works at: https://scholarship.law.gwu.edu/faculty_publications

Part of the Law Commons

\section{Recommended Citation}

Saltzburg, Stephen A., Proper and Improper Use of Other Act Evidence (2014). 29 Crim. Just. (2014) ; GWU Law School Public Law Research Paper No. 2014-64; GWU Legal Studies Research Paper No. 2014-64. Available at SSRN: http://ssrn.com/abstract=2663637

This Article is brought to you for free and open access by the Faculty Scholarship at Scholarly Commons. It has been accepted for inclusion in GW Law Faculty Publications \& Other Works by an authorized administrator of Scholarly Commons. For more information, please contact spagel@law.gwu.edu. 


\section{Proper and Improper Use of Other Act Evidence}

\section{BY STEPHEN A. SALTZBURG}

$\mathrm{R}$ ules such as Federal Rule of Evidence 404(b) and its state counterparts permit prosecutors to offer evidence that a criminal defendant engaged in uncharged misconduct to prove a number of things that may be relevant in a particular prosecution. If the government must prove knowledge and/or intent, other act evidence is often a persuasive way to do it. And, although the government is rarely required to prove motive as an element of a crime (with hate crimes being a principal exception), other act evidence that proves motive offers a powerful and persuasive explanation as to why a defendant committed a charged crime.

The most basic proposition governing rules such as Rule 404(b) is that the evidence must be offered for a permissible purpose, not to prove the defendant's propensity to commit the crime(s) charged. These rules - unlike Rules 413 and 414 -strictly prohibit the use of propensity evidence. Thus, when the prosecutor offers Rule 404(b) evidence and the defendant objects, the trial judge typically requires the prosecutor to identify the permissible purpose(s) for which the evidence is offered, rules on whether the evidence is relevant to prove the permissible purpose(s), and considers whether, even if relevant, evidence should be excluded as unduly prejudicial pursuant to rules such as Rule 403.

If the prosecutor surmounts the defendant's objections, the evidence will be admitted and the prosecutor is free to argue to the jury that the evidence does in fact prove what the prosecutor has offered it to prove. What the prosecutor may not do, however, is make an argument that amounts to a propensity argument, i.e., asking the jury to convict the defendant because he or she is the kind of person who commits the charged crime(s). But in the

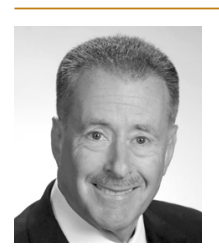

STEPHEN A. SALTZBURG is the Wallace and Beverley Woodbury University Professor at George Washington University School of Law in Washington, D.C. He is a past chair of the Criminal Justice Section and a regular columnist for Criminal Justice magazine. He is also author of the book, Trial Tactics, Third Edition (American Bar Association 2013), an updated and expanded compilation of his columns. heat of closing argument, prosecutors can slip and move from proper argument regarding the permissible purpose(s) for which the evidence was admitted into a propensity argument. Such a slip can put a conviction in jeopardy.

\section{A Sample Case: The Facts}

United States v. Richards, 719 F.3d 746 (7th Cir. 2013), illustrates how a prosecutor succeeded in having other act evidence admitted, obtained a conviction, and lost it on appeal when the appellate court determined that the prosecutor erred in making a propensity argument. Theodore Richards was convicted in district court of possession with intent to distribute cocaine. The court of appeals reversed his conviction because of the closing argument.

A joint federal and state police contingent was engaged in surveillance at a house in Bolingbrook, Illinois, where an undercover police officer was to purchase a large amount of cocaine from a highlevel drug dealer. Before the scheduled purchase, the undercover officer met with the dealer at his ranch in another city in Illinois. On the day of the purchase, the officer backed his car into the garage of the Bolingbrook house, where the dealer's men loaded 10 kilograms of cocaine into a compartment in the car that they could access through the trunk. The undercover officer then left, but other police continued surveillance of the house, as the undercover officer suspected additional drugs remained.

Twenty minutes later, a pickup truck arrived at the house and the driver got out, went inside the house, and shortly returned to the truck. A surveillance officer followed the truck and saw it meet a grey Lexus in a mall parking lot. Although the drivers did not appear to communicate, the Lexus followed the truck back to the Bolingbrook house, where the Lexus backed into the garage and the garage door closed. Ten minutes later, the garage door opened and the Lexus drove away. A surveillance officer tailed the Lexus, and upon learning that it was, indeed, cocaine that had been loaded into the undercover officer's trunk, the surveillance officer stopped the Lexus, in which Richards was driving with a woman passenger.

Although Richards had violated no traffic laws, the officer obtained a driver's license and vehicle registration in the course of questioning Richards and the passenger. Richards told the officer that he had flown in from California, had picked up the woman to go on a date, and they were on their way to get some food. The woman confirmed this story and said they had been playing video games at another house. Neither Richards nor the woman said anything about having visited the Bolingbrook house.

Police searched the car without consent and found a backpack containing 10 kilograms of cocaine. 
Both Richards and the woman denied ownership of the bag. The government ultimately charged Richards with possession of the bag with the intent to distribute the cocaine.

\section{The Defense}

Richards testified in his own behalf. His defense was that he thought the bag contained money rather than drugs. He testified that he had borrowed $\$ 50,000$ "from some Latinos that he knew collectively only as the Pelon brothers" to start a trucking company with his cousin; the company failed when his cousin (who was to be the driver) got sick; and the Pelons asked him to transport several packages for them to help repay the debt. He further testified that he had opened each of the packages - against the Pelons' orders - and found that all contained money. Richards testified that he obtained his instructions from the Pelons at their ranch, where about 30 people were "doing work and doing things" and everyone called each other "Pelon." He said he believed the Pelons wanted his trips to remain a secret because they ran businesses such as strip clubs and prostitution and may have been involved with drugs and in smuggling people over the border. Richards swore that he had been told to travel to Chicago to transport money, which is what he thought he was transporting when the police stopped and searched the Lexus he was driving.

\section{Other Act Evidence}

On cross-examination, the government asked Richards if he had ever talked on the phone with a man named Juan Beltran and whether he had talked with Beltran or another person about the need to obtain drugs. Richards admitted using marijuana but denied discussing cocaine with anyone.

The government put on a brief rebuttal case. DEA Agent Riley had monitored a wiretap on Beltran's phone in an unrelated investigation. He testified that Beltran also went by the name "Pelon," identified taped conversations in which Beltran and Richards discussed drug quantity and quality, and offered the opinion that the language they used indicated that they were talking about cocainealthough neither man specifically mentioned any drug by name.

Richards objected to the testimony on the ground that there was no evidence that Beltran was the same Pelon who had sent Richards to Bolingbrook. But the government argued that the evidence rebutted Richards's claim that he was completely ignorant of how the drug trade worked and was relevant to prove the defendant's knowledge that there were drugs in the backpack. The trial judge agreed and admitted some, but not all, of the taped conversations between Richards and Beltran.

\section{Closing Argument}

The prosecutor lost little time during closing argument in calling Richards a "cocaine dealer" and a "drug trafficker." The defense objected that this was propensity evidence, but the district judge admonished defense counsel for interrupting closing argument and instructed the jury not to infer guilt solely from evidence of past acts. The prosecutor repeated the "cocaine dealer" and "drug trafficker" language in the first closing argument. In rebuttal closing argument, the prosecutor referred to the taped Richards/Beltran conversations as "California calls" and relied exclusively on those calls to support its characterization of Richards as a cocaine dealer and drug trafficker:

- The only thing that is disputed is whether the defendant knew he had just picked up ten kilograms of cocaine. And in answering that question think about what is reasonable and what makes sense. And there is [sic] two things in particular that will help you answer that question. The defendant is a cocaine dealer and the defendant is a liar.

- But if we have met our burden on the instruction that will be given, then the California calls are absolutely relevant to knowledge and intent on November 21st. And the Judge will instruct you as much. To think that that is not relevant is absurd. He is a cocaine dealer.

- The problem is you have heard what the defendant sounds like when he doesn't think anyone is listening, when he doesn't think anyone is watching. You heard the calls. You reviewed the transcripts. When he doesn't think anyone is listening, he is a cocaine dealer. When he thinks people are watching and listening, he is back to poor me, I was just delivering money to pay back the loan. That is absurd.

- And we are not saying the ten kilos of cocaine were connected to the intercepted call from California. We are not arguing that. We are not saying that. Clearly the defendant's drug dealing is not limited to California. It happens here too.

- These layers of concealment are used to give drug dealers plausible deniability. But that doesn't work for the defendant because we already know he is a cocaine dealer.

\section{(Id. at $753-54$.}

\section{On Appeal: Admissibility of the Tapes}

The court of appeals held that the district judge did not abuse discretion in admitting the taped conversations. It found that the government offered the evidence to prove knowledge - a permissible non-propensity purpose - and that Richards had 
placed knowledge in issue when he testified that he thought the backpack contained money and not drugs The court acknowledged that in prior cases such as United States v. Miller, 673 F.3d 688 (7th Cir. 2012), it had held that prior bad act evidence is inadmissible when the defendant asserts innocence in a more general way or argues that his or her conduct fails to satisfy some element of the crime other than knowledge and intent. Miller had contended that the drugs belonged to his girlfriend and did not dispute intent or knowledge, and the court of appeals concluded that the use of prior convictions for drug offenses amounted to propensity use, whereas Richards directly and specifically disputed knowledge.

The court of appeals also found Beltran's alias of "Pelon" connected him to the ranch where Richards got his instructions. This warranted an inference that when Richards discussed drugs with Beltran, Richards knew of drug trafficking originating from the ranch. The court agreed with Richards that if the California calls had captured some generic conversation about drugs that was completely unconnected to the drug operation that caused Richards to travel to Bolingbrook, they would amount to propensity evidence if offered to prove knowledge.

Finally, the court found that the taped calls were similar enough and close enough in time to be relevant and that the district judge did not abuse discretion in rejecting a Rule 403 argument to exclude them. The court reiterated that the judge took the proper prophylactic steps to assure that no improper inference from the calls was drawn by the jury.

One judge concurred in the result. She disagreed that the judge properly admitted the California calls to prove knowledge and argued that nothing in those calls gave Richards the slightest reason to think that he would be carrying drugs rather than money when he left the Bolingbrook house. She observed that "pelon" is a Spanish word that means "Bald Guy" or "Baldy" and declined to infer anything more from the fact that a number of people called themselves "Pelon" than she would infer if they called themselves "Shorty," "Red-head," or "Curly." Thus, she argued that there was no evidence to tie Beltran to the people at the ranch.

\section{The Propensity Argument}

Although it found no error in the admission of the taped calls, the court of appeals unanimously concluded that in its closing arguments the prosecution invited the jury to draw a propensity inference from the calls. The court clearly stated that after the judge admits other act evidence for a permissible purpose, the prosecution cannot later argue that the evidence shows the defendant's propensity to deal drugs.

The court identified the "drug dealer" and "drug trafficker" language as an example of an improper propensity argument. It added that this was not the most glaring example and identified as even more glaring an argument by the prosecution that the defendant dealt drugs in California and must have done so in Illinois, too. The court concluded that the prosecution placed the forbidden propensity inference at the center of its closing arguments and prejudiced Richards, because his credibility was crucial and the government's propensity argument worked to attack that credibility.

\section{Lessons}

1. Other act evidence may not be admitted to prove propensity under Rule 404(b) and similar rules. It may only be admitted for a permissible purpose.

2. Evidence that a defendant may have been dealing drugs on some occasion may amount to propensity evidence when offered to prove something such as knowledge when the other drug evidence is completely unrelated to the crime charged.

3. Once Rule 404(b)-type evidence is admitted for a proper purpose, the prosecution must take care in closing argument not to slip and make a propensity-based argument.

4. Where the defendant's credibility is critical, propensity-based arguments may be especially prejudicial. 